\title{
The unpopularity of incentive-based instruments: What improves the cost- benefit ratio?
}

\author{
Isabelle Stadelmann-Steffen and Clau Dermont \\ Institute of Political Science, University of Berne \\ E-Mail: Isabelle.stadelmann@ipw.unibe.ch \\ Phone: $+\underline{+41316318355}$
}

Published in Public Choice 175(1-2), pp 37-62

\begin{abstract}
Whereas ecological economists argue strongly in favor of incentive-based approaches to promote renewable energy sources and reduce energy consumption, those instruments have been shown to be particularly difficult to implement politically. We begin with a recognition that cost perceptions that inherently characterize incentive-based policy instruments are a fundamental reason for their unpopularity. We therefore argue that the crucial question that policymakers need to address is how the benefit-cost ratios of incentive-based instruments can be altered in ways such that their inherent costs become acceptable. By focusing on the various features of these instruments, we propose three strategies for answering this question theoretically: objectively reduce the costs, reduce the visibility of the costs, and identify compensation strategies, i.e., strengthen the benefit side of the equation. Based on a conjoint analysis for Switzerland, our results demonstrate that reducing objective and perceived costs may indeed strengthen support for incentive-based policy instruments, whereas cost compensation does not seem to work as well. We show, moreover, that the latter can be explained by the fact that substantial numbers of voters do not understand or are not convinced by the commonly proposed mechanism of environmental taxes. Given that voters do not believe in the usefulness and efficacy of incentivebased policy measures, no cost compensation is feasible.
\end{abstract}

Keywords: Incentive-based instruments, energy policy, public support, multifactorial survey 


\section{Introduction}

Transitioning from fossil fuels and nuclear energy to a renewable energy age is a challenge for many industrialized countries. In addition to scientific progress, one of the main concerns is how to implement and promote new technologies and solutions politically. In this context, many countries have introduced "soft policies" (Carattini et al. 2016), for instance, voluntary selfregulation (Baranzini and Thalmann 2004; Ingold 2008) or traditional subsidies for renewable energies (Marcantonini and Ellerman 2014), which, however, are either not effective enough in terms of goal attainment or financially very expensive. By contrast, incentive-based steering mechanisms (e.g., incentives or environmental taxes) are widely acknowledged to be the most effective and economically efficient instruments, since they generate continuous and long-term incentives for environmentally friendly innovation and practices (Baranzini et al. 2015; Carattini et al. 2016; Deroubaix and Lévèque 2006; Jaffe et al. 2002; Mauch et al. 1992; Perry and Williams 1999; Rausch and Karplus 2014; Vollebergh 2007).

However, policymakers only recently have given more attention to such incentive-based approaches, whereas conventional environmental regulations (i.e., rules and bans) tend to be more popular with respect to practical implementation (Felder and Schleiniger 2002; Kirchgässner and Schneider 2003). One important reason for the difference is that the introduction of incentive-based policy approaches is particularly difficult, mainly owing to problems of social acceptance and political feasibility (Dresner et al. 2006, p. 896). In fact, voters seem to prefer regulation and prohibition to market-oriented policies (Deroubaix and Lévèque 2006; Kirchgässner and Schneider 2003, 375; Stadelmann-Steffen 2011). That aspect of the policy problem is particularly relevant in political contexts that integrate citizens directly into the policy-making process by means of direct democracy. Previous research has documented that citizens in their role as veto players are very reluctant to accept renewable energy policies in gen- 
eral, and incentive-based instruments in particular (Stadelmann-Steffen 2011; Thalmann 2004). Typically, this dilemma has been attributed to the cost factors that heavily impact individual vote decisions (Bornstein and Lanz 2008), but also to the fact that people fail to understand the logic and benefits of these instruments (Carattini et al. 2016). ${ }^{1}$

The present study aims at gaining a better understanding of why citizens do not support incentive-based policy instruments promoting renewable energy and reductions in energy consumption, and also whether and how their popularity might be increased. Previous research has demonstrated that the cost perceptions related to incentive-based policy instruments are one of the main reasons why those instruments are so unpopular (Kirchgässner and Schneider 2003, p. 375; Oberholzer-Gee and Weck-Hannemann 2002; Stadelmann-Steffen 2011). However, since the costs, i.e., typically new or higher taxes, are a fundamental and inherent feature of such policies, they cannot be avoided when attempting to increase their popularity. Hence, in this paper, we argue that the crucial question that policy makers need to address is how the unpopular costs of a policy proposal can either be reduced or compensated for. In other words, the following is the main research question of the present study: Which features of incentive-based policy instruments can alter the cost-benefit equation in a way that inherent costs become acceptable?

Incentive-based instruments, in this article, are conceptualized as incentive packages that contain a tax and/or a subsidy. From the citizens' perspective these instruments therefore have a cost side (generating some revenues for the state) and a benefit side (related to how the revenues are spent/redistributed by the state). Thus, our main interest is on the specific design of a policy, i.e., the elements of a policy instrument (Howlett et al. 2009). Policy instruments have been

\footnotetext{
${ }^{1}$ In a similar vein, also some (usually large) firms in the energy industry prefer command and control regulations to taxes because the former can be influenced to gain competitive advantages over their smaller rivals.
} 
defined as the measures of state action adopted to solve a political problem (Cairney 2011). In the literature, in addition to persuasive measures, the main distinction is between incentivebased and regulatory policies (Vedung 1998). In the following sections, we argue that to explain policy support (by citizens), we need to go beyond this dichotomy and consider the various elements of a policy proposal more specifically (see also Kemp and Pontogio 2011; Vollebergh 2007, p. 3). For example, the design of an energy tax has many possibilities. First, the question arises as to what is taxed, i.e., fuels and combustibles, electricity coming from non-renewable sources or electricity in general. Second, a tax can vary as to whom is taxed, i.e., consumers and/or producers. Third, the tax rate can be higher or lower. Fourth, the revenues collected through such taxes can be spent differently: the money can be allocated to promote renewable electricity production, or it could be redistributed to citizens (in different ways). These brief examples show that one policy proposal contains myriad dimensions, out of which some may be more popular, whereas others may be contested.

The present study contributes to the existing literature in three respects. First, theoretically, it combines public choice reasoning about individual cost-benefit calculations with an understanding of policy support as involving multidimensional choices. That approach not only helps to provide an understanding of an instrument's low popularity, but also involves some strategies for policy design that may help to increase public support for these instruments. Second, and relatedly, the present study conceptually proposes a decomposed perspective on incentive-based policy instruments by focusing on their various elements. Such a strategy accords with previous research concluding that the impact of environmental policy instruments may depend more on design features than the general instrument type itself (Kemp and Pondogio 2011, p. 34). We expand that reasoning to the social acceptance of incentive-based instruments. Third, empirically, we present the results from a novel, large-scale representative survey from Switzerland. A forced-choice paired conjoint analysis (Hainmueller, Hopkins and Yamamoto 
2014) enables us to evaluate how specific aspects of an incentive-based policy proposal influence individual support for or rejection of a whole proposal. Our approach helps us to identify the drivers and red lines for the popular support of a proposal. The Swiss case is particularly suitable in this respect, since citizens_owing to the frequency of direct-democratic ballots-are familiar with this kind of personal decision-making and with indicating their support or rejection of (alternative) policy solutions. Furthermore, by using our experimental approach, we are not limited to already existing policy solutions, but rather are able to take an ex-ante perspective on citizens' voting preferences in the near future.

The remainder of the present study is structured as follows. In the following section, we present our theoretical framework by discussing different mechanisms that may alter the benefit-cost ratio of incentive-based renewable energy policy instruments. Next, we introduce the methodological approach, the data and their operationalization. In section 4, we present our empirical findings. The study ends with a summary of the most important results and conclusions.

\section{Theory}

As mentioned in the introduction, the starting point of this study is a puzzle regarding the choice of policy instruments for environmental policy in general and energy policy in particular. In that context, environmental economists argue strongly in favor of incentive-based approaches (Carattini et al. 2016; Deroubaix and Lévèque 2006; Jaffe et al. 2002; Mauch et al. 1992). What is most important, incentive-based policy instruments are considered to be most effective for environmental protection in the long-run, since they generate continuous and long-term incentives for environmentally friendly innovation and practices. ${ }^{2}$ Moreover, some researchers have

\footnotetext{
${ }^{2}$ However, empirically, the superiority of incentive-based instruments is less clear. For example, it has been shown that the effectiveness of incentive-based instruments may be limited re-
} 
argued for the economic advantages of incentive-based approaches (Carrattini et al. 2016; OECD 2008; Rausch et al. 2014). However, such policy instruments have been shown to be particularly difficult to implement politically, whereas conventional regulatory approaches (i.e., rules and bans) tend to be more popular for purposes of practical implementation (Felder and Schleiniger 2002; Kirchgässner and Schneider 2003). Moreover, voters seem to prefer policies of regulation and prohibition over market-oriented policies; so, too, do regulated firms (Deroubaix and Lévèque 2006; Kirchgässner and Schneider 2003, p. 375; Stadelmann-Steffen 2011).

Scholars have demonstrated that the cost perceptions that characterize incentive-based policy instruments are a fundamental reason for their unpopularity. Based on the public choice approach, Kirchgässner and Schneider (2003, p. 375) have argued that with respect to environmental policy, voters generally must choose between a better quality environment (in the future) and a higher real income today, and they tend to prefer the latter (see also Bornstein and Lanz 2008). In general, that preference may lead to an insufficient supply of environmental policies. Moreover, the individual cost-benefit calculation may be biased towards traditional regulatory policies in which costs are less visible to voters compared to incentive-based instruments: "voters may have the impression that an improvement of the environment could be reached by means of regulations and prohibitions without costs, i.e., without reducing the income of the average citizen” (Kirchgässner and Schneider 2003, p. 375). That “cost-illusion” (Schulz 2011) implies that traditional policies are perceived to be more equitable and fairer (Deroubaix and Lévèque 2006, p. 947).

garding large-scale innovations (e.g., Kemp and Pontogio 2011) and, more generally, because of a rather inelastic demand for energy in the short-run (OECD 2006, p. 50). 
To put it bluntly, the nature of environmental policy in general and incentive-based instruments in particular lead to a situation in which the costs related to a policy proposal are immediately tangible and visible for individual households, whereas the potential benefits of the policy are much less so. In the following section, we begin with a recognition that the costs, i.e., typically new or higher taxes, are an inherent feature of such policies. Thus, the crucial question that arises is how the individual benefit-cost calculation related to incentive-based instruments can be altered to raise support for those instruments. By focusing on the various elements of such instruments, we propose three strategies for answering that question: objectively reduce the costs, reduce the visibility of the costs, and offer compensation, i.e., strengthen the benefit side of the equation.

\subsection{Reducing objective costs}

The most obvious way to reduce the visible costs is to really reduce the costs. Thus, lower tax rates bring the personal costs of the policy down and increase the probability that the individual benefit-cost ratio will be positive. Previous research has demonstrated that popular support for green taxes is greater when the tax is small and many exceptions are available, e.g., for energyintensive firms (Buchanan and Tullock 1975; Thalmann 2004). Although that strategy may make incentive-based instruments more socially acceptable, it also may reduce the environmental impact of those instruments, a tradeoff that typically characterizes environmental policy instruments (Goulder \& Parry 2008; OECD 2008, p. 13). Nevertheless, we formulate the following hypothesis:

H1: The lower the objective costs are for households, the greater will be public support for incentive-based policy instruments. 


\subsection{Reducing perceived costs}

The cost factor in the individual benefit-cost calculation also could be altered by changing the perceptions of cost, which are related to their visibility (OECD 2006, p. 152). Although we have argued previously that incentive-based policy instruments are characterized by very visible costs, visibility is still a matter of degree. Variations in incentive-based instruments may create varying individual perceptions of the costliness of individual instruments. Incentive-based instruments typically involve taxes, which can be used to provide incentives to reduce non-desired behavior (e.g., taxes on electricity consumption), or to finance policies that stimulate desired behavior (e.g., grants-in-aid or feed-in tariffs, i.e., guaranteeing prices for fixed periods of time for electricity produced from renewable energy sources; see Goulder and Parry 2008; Howlett 2005; Howlett and Ramesh 1993; Windhoff-Héritier 1987). In that context, Gingrich (2014) has argued that direct taxes (on income or revenue) are more salient to citizens than indirect taxes (on consumption). In other words, direct income and revenue taxes are perceived as costlier and more inescapable than indirect ones. Moreover, regarding the latter, a consumption tax that follows the "user pays" principle may not only appear avoidable to a certain extent, i.e., my personal behavior can influence how much I have to pay, but also better represent the norms of fairness and equality. Those latter aspects have been shown to be important triggers for public acceptance, mainly with respect to implementation processes (OECD 2006, p. 151, Wolsink 2007), willingness to pay (Aijzen et al. 2000) and compliance with such measures (e.g., Hartner et al. 2008)—which implies that the arguments concerning fairness and equality also can be used to support policy measures:

H2: Incentives funded by indirect taxes that follow the "user pays" principle rather than by direct (income) taxes are more likely to be supported by citizens. 


\subsection{Compensating the costs, or how to strengthen the benefit side}

The third strategy is to alter the benefit side of the benefit-cost equation. In other words, incentive-based policy instruments need to provide some (perceived) benefits to voters that compensate for the instruments' costs. In other policy areas, particularly regarding welfare state reforms, compensation has been identified as a crucial mechanism for increasing public support of a proposal (Bonoli 2000; Häusermann 2010; Häusermann et al. 2016). Structurally, however, as previously discussed, incentive-based policy instruments are dominated by (short-term) costs, whereas a benefit, i.e., better environmental quality, tends to materialize only in the long-run and remains to a certain degree uncertain. In this context, we suggest two mechanisms by which compensation may occur.

On the one hand, a measure may provide some material benefit. For example, when implementing an environmental tax, the revenues collected from taxes on electricity or energy consumption may be redistributed to the taxpaying public. According to Kirchgässner (1997; see also Thalmann 2004), fully redistributing revenues from green taxes might be an important trigger for popular support. From a personal cost perspective, redistribution means that electricity-saving behavior may result in a financial benefit. In contrast, another classic example of an incentive-based policy instrument is the provision of economic incentives for technological innovation (e.g., investment funds, feed-in tariffs). From a household's perspective, such policies are dominated by the cost side: households pay through taxes, whereas the main beneficiaries are business enterprises (and maybe also a small group of consumers, i.e., so-called prosumers). Hence, taking the cost compensation argument seriously, citizens should prefer redistribution over investment- or a performance-based instrument:

H3: Citizens prefer incentive-based instruments that redistribute tax revenues to the taxpayers rather than spending the revenue on promoting the production of renewable electricity generation. 
A second compensation mechanism works when voters are convinced that a policy instrument will have a future benefit, and when they hold a favorable attitude towards the target of that instrument. Put simply, if an individual thinks that a policy measure will be useful and effective for reaching a goal she/he supports, he/she will be more likely to be willing to bear the costs. Quite clearly, believing in the usefulness of renewable energy policies is contingent on environmental and ideological attitudes (we discuss this relationship in more detail below). However, we argue that the perception of how useful and effective an incentive-based instrument will be also depends on policy design, i.e., the measures that an incentive-based instrument contains. During the last decade, for example, feed-in tariffs have been considered to be the most effective tool for promoting the acceleration of renewable energy production (Couture and Gagnon 2010). In contrast to investment-based policy measures, feed-in tariffs reward actual performance. However, most recently and against the background of the German experience, feed-in tariffs also have been criticized for being inefficient and too expensive owing to the over-market prices paid to the producers of renewable electricity. ${ }^{3}$ This discussion may have influenced some citizens’ perceptions of feed-in tariffs’ usefulness.

H4: Citizens prefer incentive-based instruments that they perceive to be useful and effective means for achieving a formulated target.

\subsection{The logical extension: Differences based on ideological predisposition?}

\footnotetext{
${ }^{3}$ For example, see “Are the Legacy Costs of Germany’s Solar Feed-In Tariff Fixable?” http://www.greentechmedia.com/articles/read/germany-moves-to-reform-its-renewable-energylaw (retrieved on August 4, 2016) or “Ineffizient und zu teuer" http://www.nzz.ch/meinung/kommentare/ineffizient-und-zu-teuer-1.18657976 (retrieved on August 4, 2016).
} 
As mentioned previously, and even from a public choice perspective, citizens' decisions on renewable electricity policies can be expected to be influenced by political and environmental values. Most generally, it has been show in various contexts that a left-green ideology, i.e., rating environmental protection as important, corresponds with a greater likelihood of voting environmentally friendly (Bornstein and Lanz 2008; Bornstein and Thalmann 2004; Deacon and Shapiro 1975; Halbheer et al. 2006; Kahn and Matsusaka 1997, Sciarini, Bornstein and Lanz 2007; Stadelmann-Steffen 2011). However, and most important in our context, ideological factors might not only affect the general electoral support for energy policies that promote renewable energy production and lower energy consumption, but also affect the costs and benefits of the voting decision (Bornstein and Lanz 2008, p. 431). For instance, given that center-right individuals tend to have weaker pro-environmental values (Bornstein and Thalmann 2004; Sciarini, Bornstein and Lanz 2007), the cost argument should particularly matter for their voting behavior. In contrast, leftwing voters may not only support more strongly the goal of renewable energy policies, but also be more inclined to believe in the usefulness and efficacy of these policies. Hence, a favorable attitude towards cost compensation may be more likely to occur in the latter voter group.

In accordance with Bornstein and Lanz (2008, p. 431), considering ideological factors in an analysis of vote choice is not only a "logical extension" of the public choice approach, but also is important for capturing potential varying cost and benefit effects. Hence, to grasp the potentially different perceptions and evaluations of benefit-cost considerations by different voter groups, we examine whether the role of specific policy instrument features vary contingent on a citizen’s ideological predisposition.

\section{Research design}

\subsection{The methodological approach: A conjoint analysis}


From the literature and the specific research question at hand, two major issues arise when investigating citizens' support for proposals to promote renewable energy production and reduce energy consumption. First, support needs to be captured in a way that actually reflects voting behavior and not only mere opinions; second, we should recognize that support for incentivebased policy measures at the ballot box involves multidimensional choices, i.e., a specific ballot proposal consists of various elements out of which a voter may like some while rejecting others. Therefore, an individual vote decision is the result of balancing the pros and cons of a proposal.

Both issues can be approached methodically by implementing a factorial survey experiment in which respondents are asked to rate various policy proposals (see Fig. 1). In contrast to single-item questions (e.g., "Would you support an incentive tax to reduce energy consumption?”), the results of a factorial survey experiment reflect preferences for various designs of energy policy proposals and thus get closer to a realistic vote decision for which not a single attribute but a combination of multiple factors is relevant to the vote choice. Methodologically, this paper follows Hainmueller et al. (2014) and Bechtel et al. (2015) by applying a randomized conjoint design. Since each respondent is exposed to seven paired policy proposals, we were able to collect enough information on all of the different attribute combinations.

To contextualize the stated preferences experiment, we explicitly asked respondents to envisage their decision as a vote that would be cast on the following Sunday. For each paired policy variant, respondents had to indicate which one she/he would choose in a confrontational vote (choice answer) as well as for both proposals individually, i.e., "how likely they would approve the variant in a referendum” on a scale from $0 \%$ to $100 \%$ in decimal steps (support answer). Such a design corresponds to a realistic ballot situation in Switzerland when the government presents a counterproposal to a popular initiative. In that case, citizens are asked (1) whether they are in favor of the two presented proposals individually and (2) which proposal they prefer if both receive a majority of votes. Thus, the electorate can accept both proposals on 
the ballot (i.e., both proposals can receive more than 50\%). If so, the proposal that receives more votes breaks the tie and will be implemented. More generally, the frequency of directdemocratic ballots in Switzerland implies that Swiss respondents are quite familiar with the decision situation mimicked in the conjoint analysis, which can be expected to increase the validity and consistency of their responses.

--- Fig. 1 about here ---

Although an experiment never has the same consequences as a real-world vote and therefore by definition has advantages mainly with respect to internal rather than external validity, we argue that the chosen conjoint design offers ideal conditions for analyzing voter decisions at the ballot for several additional reasons. First, we argue that deciding based on a conjoint table (see Fig.1), i.e., the key elements of a proposal, corresponds quite closely to voters' real-world decision-making. On the one hand, many citizens are likely not to be informed at a profound level about the proposal at stake, but rather take several key points mentioned in the pre-ballot campaign (and party positions) as cues for voting yes or no (Kriesi 2005, 2012; also see Chong \& Druckman 2007; Druckman 2001; Lupia 2015). In that sense, the effect of the abstract content in a conjoint table (for example, compared with a vignette design) plausibly corresponds to mentioning the main issues that arise during a campaign, which eventually are weighed by citizens in making their decision. Second, the factorial survey experiment approach captures a citizen’s behavioral component by asking for his/her likely support (voting yes) instead of how she/he feels about a certain policy instrument without providing the context of a specific policy proposal. Hence, we argue that the factorial survey design not only enables us to at least partly overcome the value-action gap (Bell et al. 2013; Kollmus and Agyeman 2002), 
but also brings us closer to measuring actual support (van Rijnsoever et al. 2015; Dermont, Ingold, Kammermann and Stadelmann-Steffen 2017) for the energy policy proposals studied. Third, a conjoint choice experiment perfectly fits our theoretical argument in that the support for policy instruments depends heavily on their specific components and how important it is to identify the combinations of those components that are most popular among citizens (Hainmueller et al. 2014: 3). Fourth, environmental policy questions are prone to a social desirability bias, i.e., people pretend to be more environmentally-friendly in surveys than they actually are. Conjoint experiments provide respondents with multiple reasons to justify a particular choice and rating, and thus have the potential to reduce social desirability bias (ibid.).

\subsection{Data}

The analyses presented herein are from Switzerland, the home of the most direct democratic decision making in the world. In the discussions about a transition from nuclear and fossil fuels to renewable sources of energy, the Swiss government in its Energy Strategy 2050 proposed, among other things, a steering scheme that minimizes state intervention as a long-term aim (Swiss Confederation 2015). Although a first set of measures that focused on the promotion of renewable energy production and greater energy efficiency was supported in a popular vote on May 21, 2017, still up for debate are whether and how to introduce such a steering system.

The data set used in this contribution was collected between March and May, 2016. The trilingual survey ${ }^{4}$ on future energy provision in Switzerland contains 8,287 responses from a

\footnotetext{
${ }^{4}$ The survey was conducted in German, French, and Italian, the three most frequently spoken of Switzerland's four national languages. Participants filled out the survey $65.4 \%$ in German, $26.0 \%$ in French, and $8.6 \%$ in Italian. Romansh individuals likely used the German version to respond to the survey.
} 
representative sample provided by the Federal Office of Statistics, whereby respondents where invited by postal mail to participate in an online survey. ${ }^{5}$ The response rate after three invites was $41.7 \%$. The demographic and structural composition of the final sample corresponds quite closely to the Swiss resident population (see Table A.2. in the Appendix). This is particularly true with respect to gender, civic status, and education. Foreigners living in Switzerland as well as citizens over 75 years of age had lower response rates, which likely is explained by the exclusive use of an online survey. In terms of political orientation, the collected sample is very similar to the composition of Swiss voters according to the Swiss Election Study 2015 (Lutz 2016), the exceptions being that support for the larger parties is comparatively stronger in our sample, and the ideological positions of the respondents on the left-right scale is somewhat less polarized.

The survey comprised two conjoint modules, whereby respondents were assigned randomly to one of the two. The module on policy support used in the present paper was answered by 4,146 individuals.

A second data source on which we relied for the empirical part of our study is a survey that was conducted after a vote on a popular initiative called the "Green economy" in September 2016. That initiative, which was rejected clearly by the citizenry, aimed at committing the country to achieving a sustainable use of natural resources by 2050. The survey included five items (see Table A.4 in the Appendix) relating to the economic modeling assumptions of environmental taxes to capture respondents' agreement or disagreement with those assumptions.

\footnotetext{
${ }^{5}$ The data collection process was conducted by the LINK Institute in Lucerne. The sample was provided by the Federal Office of Statistics from the "Stichprobenrahmen für Personen- und Haushaltserhebungen” (SRPH).
} 
The sample representative of Switzerland was provided by Qualtrics, and also was conducted in three languages.

\subsection{Operationalization and implementation}

The main dependent variable indicates support for a given combination of attributes presented to individual survey respondents. Support for each proposal was recorded based on the rating question, i.e., individuals had to indicate how likely they were to cast a yes vote on a proposal at the ballot box (see Fig. 1). ${ }^{6}$

The conjoint setup varied on seven attributes (for a detailed description of the attributes, attribute levels and weights see Table A.1 in the Appendix), whereby-according to our hypotheses - we focus on three attributes for our analyses: the policy measure, how the measure is funded, and additional monthly cost per household. Moreover, four other attributes accounted for varying energy sources, the measure's running time, whether exceptions are provided for energy intensive industries, and how to treat nuclear power plants. We presented the policy proposals at random, i.e., reflecting random combinations of attribute levels. The exceptions were

\footnotetext{
${ }^{6}$ Although the question format differs from a ballot context in which citizens must cast either a yes or no vote, similar rating questions typically are used in pre-poll surveys in Switzerland. It seems to be a suitable way of reducing the number of "don't know” answers in a situation in which citizens may not (yet) be totally sure about whether to approve or reject a proposal. To test the robustness of our results, we also estimated the model using a binary coding specification, i.e., individuals who indicated a high probability of voting yes (values of 8 or more out of 10) were assigned a 1 (“support”), whereas all others were coded as 0 (“not support”). The results can be found in Figure A2 in the Appendix, and are almost identical to those presented in the main part of this paper.
} 
for some illogical combinations of attribute levels, which we excluded. We used weights to account for these constraints in the estimations.

The seven attributes were defined based on current public and political debates, and thus reflect "real" possible solutions for reducing the consumption of electricity and/or for the promotion of renewable electricity production in Switzerland. Since some of the elements of the presented policy proposals were less well known by the electorate (given that no political campaign on those issues was being carried out at the time of the data collection), we tried to provide some basic information on issues mentioned in the survey (explanations of the different energy sources and feed-in tariffs, among others). In addition to pop-up information, we placed a module with single-item questions on energy policy before the conjoint module to encourage respondents to reflect on these issues before answering the conjoint questions. In this vein, we compensated to a certain extent for the lack of a publicity campaign that usually precedes individual decision making.

Owing to the experimental setting and randomized presentation of attributes, and since our interest is in the marginal effects of policy features, the models do not consider control variables. However, to test whether the average marginal component effects (AMCEs) vary between societal groups, we estimated further models that considered the interaction effects of demographic and socio-economic characteristics (age, gender, education and language region). Those models, which are available in the supplementary material, demonstrate that the results presented in the next section are quite consistent across groups.

\section{Results}

In this section, we present our empirical findings. First, we discuss the mean support rates across all policy packages-i.e., all possible policy combinations that were shown to the respondents—so as to estimate the actual (un)popularity of the different variants of incentive- 
based proposals. In the second step, we focus on the specific elements of the policy combinations to test our hypotheses empirically. Finally, in a third empirical step, we consider the differences in support for incentive-based policies that depend on voters' ideological predispositions.

Fig. 2 documents the mean support rates across all possible policy proposals. Initially, it can be seen that the variance in mean support is considerable, ranging basically from almost zero to almost complete support. That finding must be considered against the background that the random combination of the seven policy attributes generates a lot of reasonable policy alternatives, but also produces some very extreme ones (e.g., a very expensive, long-lasting consumption tax whereby revenues would be spent primarily on geothermal power) and some that would barely change anything compared to the status quo (e.g., a feed-in-tariff for renewable energy sources at no additional cost).

However, the most important observation is that a majority of the proposals reaches a mean support of less than $50 \%$ (the plot has its highest density below a $50 \%$ support rate), which confirms that, on average, incentive-based policy proposals cannot build on broad popular support. Nevertheless, Fig. 2 also illustrates that a potential exists for incentive-based instruments to be accepted at the ballot box: for a considerable number of the incentive-based proposals (35\%), a majority of the respondents indicated that they would (more) likely cast a yes vote. Hence, the question arises as to the characteristics of these potentially successful policy proposals.

--- Fig. 2 about here ---

\subsection{Varying components of an electricity proposal: What improves the cost-benefit ratio?}


To test which attributes hinder or boost support for a proposal, we rely on the so-called AMCE, which represents the "marginal effect of attribute averaged over the joint distribution of the remaining attributes” (Hainmueller et al. 2014, p. 10). Fig. 3 depicts the results of the conjoint analysis of the three attributes on which we focus.

Initially, we indeed observe that individuals rely heavily on the cost argument. As soon as a proposal involves any additional costs for households, the likelihood that an individual will support the proposition declines. These results strongly corroborate our crucial assumption that the cost factor is an inherent hurdle to citizens’ supporting incentive-based policy instruments. Moreover, the level of costs matters: a more or less linear and negative relationship exists between rising costs and the probability that a proposal will be supported by respondents. In other words, and in accordance with Hypothesis 1, the lower the costs involved, the more likely citizens are to support an incentive-based policy proposal.

According to Hypothesis 2, the role costs play in benefit-cost calculations also depends on the visibility of costs, and more precisely on how the money is collected. The analyses show that on the funding side, a consumption tax on electricity is preferred by citizens over proposals funded through general direct taxes or a value added tax (VAT). Put differently, policy measures that are funded by taxes on (non-renewable) electricity consumption are more likely to be supported by respondents than proposals that aim at funding measures financed by direct taxes or the VAT. Hence, these findings can be interpreted to mean that Swiss citizens generally support the "user pays" principle, which might be seen as fairer compared to general taxes. That result fits our theoretical expectations that less visible and more "escapable" costs receive stronger support from citizens (Hypothesis 2). However, the probability that respondents will support a specific proposal does not depend significantly on their choosing between the alternatives of taxing electricity consumption in general (i.e., from renewable and non-renewable sources) or electricity consumption generated only from non-renewable sources. 
--- Fig. 3 about here ---

With respect to cost compensation (Hypotheses 3 and 4), we argued that citizens would prefer incentive-based instruments that involve some material benefits (e.g., redistribution of tax revenues) or perceived gains, i.e., the usefulness and efficacy of a policy measure. However, the estimation results initially demonstrate that citizens seem largely to be indifferent about the policy measure on the spending side. Their support is independent of whether the tax revenues are redistributed to the population or used to promote renewable energy production more specifically (e.g., through feed-in tariffs, investment grants, or tax relief). ${ }^{7}$ Thus, the empirical evidence does not support Hypothesis 3, which suggests that citizens would-based on a benefit-cost calculation-prefer a redistribution of tax revenues, which may even imply a material benefit for those who consume less energy. Similarly, the results also do not imply that citizens would be more supportive of measures aimed more directly at the target of a policy, e.g., investment grants or feed-in tariffs, which would make the effect (i.e., a benefit) more tangible and salient, as stated in Hypothesis 4.

The explanation for this non-finding is at least twofold. On the one hand, the insignificant AMCE for the policy measures could just reflect a real and informed indifference to them. On the other hand, the indifference to the policy measures also could imply that citizens have difficulties understanding the varying incentive-based possibilities for reaching environmental targets, and in particular the logic of environmental taxes (Carrattini et al. 2016; OECD 2006; Thalmann 2004). If citizens do not understand or acknowledge a measure's intended benefits, it

\footnotetext{
${ }^{7}$ Further analysis not presented here, moreover, revealed that indifference between policy measures persists if the policy measures are interacted with the source of funding.
} 
may not be considered in individual decision-making (statistically speaking, that attribute is not relevant to explaining policy support). Since a lack of information about a policy instrument could thus be an important reason for rejecting the unknown, support for incentive-based instruments could be strengthened by informing citizens about the economic assumptions underlying such instruments.

With respect to our research question, the latter interpretation is particularly relevant. From the perspective of Hypothesis 4, it is quite clear that if people do not know or believe in the usefulness and efficacy of an environmental policy measure, any compensation related to its cost burden will not be made. Based on our original data, similar to previous research (e.g., Carrattini et al. 2016; Thalmann 2004), we could not test whether citizens actually understand and believe in the effectiveness of environmental taxes. For that reason, we integrated a five-item question into another population survey that focused on the popular initiative "Green economy," which the Swiss people voted on in September 2016. The results are presented in Fig. 4.

--- Fig. 4 about here ---

As Fig. 4 illustrates, a plurality (rather) agrees that redistributing revenues from an energy tax to the taxpaying population does not lead to a reduction in energy consumption, and puts additional strain on public finances. These two findings demonstrate clearly that the economic assumptions of redistributive environmental taxes were not acknowledged by roughly half of the respondents. Interestingly, the opinions on the mechanisms of environmental taxes largely are independent of ideological predispositions (see Fig.A1 in the Appendix). However, that pattern has one exception: voters on the left side of the political spectrum are more strongly con- 
vinced that a steering tax, i.e., a scheme where revenues from an environmental tax are redistributed to the taxpaying population, actually reduces consumption. Overall, the findings support the conclusion that a substantial number of Swiss citizens do not believe in the neoclassical economic model and the assumptions underlying steering taxes, or do not understand their economic implications. Hence, this finding further corroborates the conclusion that Hypothesis 4 fails to be supported based on its fundamentals: given that citizens do not understand or believe in the efficacy of incentive-based policy instruments, a perceived benefit does not exist that could compensate for the costs.

\subsection{The influence of predisposition}

In a last analytical step, we examine the extent to which political ideology influences citizens' decision-making on renewable energy policies, and in particular benefit-cost considerations. Fig. 4 depicts conditional AMCEs for respondents with left, middle, and right political predispositions as measured by their self-reported political ideologies. As discussed in the theoretical section of the present study, we particularly expect that voters from the political center and right will weight cost arguments more heavily than those from the left, whereas the latter may be more inclined to believe in the usefulness and efficacy of renewable energy measures.

--- Fig. 5 about here ---

However, the main message we take from Fig. 5 is that the patterns across the political left-right spectrum are astonishingly similar. Most importantly, voters across the political spectrum do not have clear preferences on environmental policy measures (i.e., feed-in-tariff, investment grants, tax relief or redistribution). For example, right-wing voters do not support 
more strongly a pure steering system that would go along with limited state intervention, and left-wing voters do not express stronger support for measures that explicitly promote renewable energy production. However, Fig. 5 does indicate that left-wing voters tend to be slightly less averse to additional costs than voters from the political center and right, even though the general pattern does not differ. In addition, centrist and right-wing voters show stronger preferences for funding renewable electricity through an energy tax rather than by levying general direct or indirect taxes, whereas for leftist voters, no significant differences exist between the sources of funding.

Thus, voters with different ideological predispositions do not vary much in their weighting of different policy components. However, Fig. 6 illustrates that the mean support across all possible policy combinations does differ between the ideological groups. As expected, support for policies to promote renewable energy and reduce energy consumption is greatest for leftist voters, whereas voters in the middle and the right of the political spectrum are less likely to support such proposals in a popular vote (the means, represented by the dashed lines in each density plot, drop from $49.5 \%$ to $46.3 \%$ and to $43.9 \%$ for voters in the middle and the right, respectively). Also, those differences show that approval rates for all ideological groups vary between total opposition to total support. As mentioned previously, the sample of proposals contains a very diverse set of policy combinations, including both very far-reaching proposals as well as policy combinations that would not contribute much to achieving environmental policy targets. Therefore, this diverse set of policy combinations gives both environmentally friendly (typically left-wing) respondents and those who are more reluctant to support environmental policies (typically rightist individuals) reasons to (strongly) support some policies and (strongly) reject others. Considering all the combinations, the average still exhibits a small but relevant difference for support for all possible policy proposals to promote renewable energy generation. 
--- Fig. 6 about here ---

\section{Conclusion}

The starting point of the present study was the puzzle about why citizens are reluctant to accept incentive-based energy policies even though such instruments are widely acknowledged by economists and policy makers to be the most effective means of attaining the goals of environmental policy in general and energy policy in particular. We argued that to learn more about the political difficulties of implementing incentive-based policy instruments, we should go beyond the traditional distinctions between incentive-based, regulatory and persuasive instruments, and look more closely at the varying elements of which specific incentive-based instruments consist. Most importantly, we showed that incentive-based policies are characterized by a particular cost structure, i.e., those instruments inherently involve some costs that typically are visible to voters. Hence, the main question that arises_-which is the focus of the present study—is what features and mechanisms could compensate for or reduce those inherent costs and thus increase citizens' support for the policy instruments. Thus, we proposed and empirically tested three mechanisms that may alter the benefit-cost ratios of incentive-based instruments: reducing the objective costs, reducing the perceived costs, and increasing the benefits. Based on a conjoint analysis conducted in Switzerland, the main findings of our analyses are summarized in the following paragraphs.

Most importantly, our results demonstrate that reducing objective and perceived costs may indeed strengthen voter support for incentive-based policy instruments, whereas cost compensation does not seem to work as well. More precisely, our findings suggest that costs are still the most relevant factor influencing individual decision-making with respect to incentive-based instruments. The analyses reveal that the negative relationship between costs per household and 
policy support essentially is linear. In other words, designing an incentive-based policy instrument in a modest way, i.e., limiting the visible costs, will increase its level of support. That finding not only accords with previous research suggesting "gradual implementation” of these instruments (Dresner et al. 2006; OECD 2006), but also is in line with recent findings from Switzerland, which identified low household costs as an important factor underlying the success of the new energy law accepted by Swiss citizens in May $2017 .{ }^{8}$ Of course, the downside of that policy mechanism is that a lower energy tax, for example, also will limit its efficacy. Moreover, and regarding the perception of costs, the analyses in the present study support the view that incentive-based policy instruments are more likely to be supported if they involve taxes perceived as fair and to a certain degree avoidable. In that context, the "user pays" principle is widely accepted by citizens and is clearly preferred over general income taxes or the VAT.

In contrast, the results suggest that no policy measure has a clear positive effect on the support for incentive-based instruments. Thus, we found no evidence that a particular measure to promote renewable energy could increase the perceived benefit of a policy proposal and thus compensate for higher costs in the benefit-cost ratio. Most interestingly, an instrument that redistributes tax revenues back to the taxpaying population, and thus most clearly involves a material benefit, seems not to increase support more than proposals requiring the state to invest in the promotion of renewable energy production. Based on additional data, we were able to show that substantial numbers of voters, sometimes even a majority, do not understand or are not convinced by economic arguments favoring environmental taxes, an aspect of such policy measures that often has been assumed, but never has been tested explicitly before (see also Carattini et al. 2016; Clinch and Dunne 2006). That phenomenon imposes tight constraints on popular support for those policy instruments. To put it bluntly, since citizens do not understand

\footnotetext{
${ }^{8}$ http://www.defacto.expert/2017/07/18/das-ja-zum-energiegesetz-breite-zustimmung-zur-
} energiestrategie-oder-hart-erarbeiteter-erfolg/ (retrieved: November 22, 2017). 
or believe in the usefulness and efficacy of incentive-based instruments, why should they be ready to pay for and thus support such proposals? Thus, in the context of environmental measures that may provide benefits to society in a general way (i.e., as public goods), but not necessarily to individuals specifically, ${ }^{9}$ policy makers need to better explain and suggest to voters why incentive-based instruments can deliver benefits in the longer-run.

Furthermore, when taking into account political ideology, our findings demonstrate an astonishing similarity amongst voter groups. Whereas, theoretically, we expected differences in benefit-cost considerations between voter groups, our analyses show that, across all parts of the political spectrum, voters seem to focus heavily on cost arguments, whereas a measure's specific elements are much less relevant. Ex ante support for incentive-based energy policies is in general, and across the full political spectrum, rather lukewarm, which points to the crucial importance of pre-ballot publicity campaigns. Although our survey has been carried out in a noncampaign context, future research could look profitably at whether and how preferences for various policy proposals change during a public debate.

Although the present study focused on Switzerland and cannot necessarily be generalized to other contexts, we argue that our main results are relevant beyond the Swiss case. Taxes and steering systems vary between nations and across sub-national jurisdictions, but they are based on "universal” economic models and generally consist of rather complex bundles of policy measures. Hence, it can be assumed that a lack of understanding about, and acknowledgment of, the economic assumptions of incentive-based policy instruments are also realities in other contexts and, hence, also may be important factors for the broader unpopularity of such instruments (also see OECD 2008, p. 25). A lack of popular support for incentive-based policy measures also may hinder their implementation in purely representative political systems in

\footnotetext{
${ }^{9}$ However, exceptions, such as increases in property values, are possible (see Deacon and Shapiro 1975).
} 
which governments might be reluctant to promote such unpopular policies owing to fear of electoral punishment. Still, more research is needed to clarify these results and, most importantly, to investigate their policy implications. First, it remains an open question whether incentive-based instruments are victims of their own non-success. In fact, according to economic models, incentive-based instruments would be most effective if the disincentives for non-desired behavior (e.g., energy consumption) were strong. However, because of the political challenges of introducing such effective instruments, existing taxes typically are rather low. Thus, even if economic models were right, their real-world benefits (e.g., reduced energy consumption) may currently be limited because incentives are too weak. In turn, that lack of success can further hinder citizens’ support for economic models. Moreover, and coming back to the question of whether and how the popularity of these instruments could be strengthened , our results imply that information and communication may play important roles in increasing public support for incentivebased measures. In this vein, further research should reflect on when and how to inform citizens so to fill their knowledge gaps, and also to convince them that economic models can meet their expectations in the real world.

Acknowledgment: This research was conducted within the National Research Programme “Managing Energy Consumption“ (NRP 71) funded by the Swiss National Science Foundation and supported by the IMG Foundation. We thank Philippe Thalmann and the anonymous reviewers for helpful comments on earlier versions of this article, and Wayne Egers for linguistic assistance. 


\section{Appendix}

Table A.1. Attribute list and levels used in the conjoint analysis.

\begin{tabular}{|c|c|c|}
\hline ATTRIBUTES & LEVELS & WEIGHTS / CONSTRAINTS \\
\hline Energy Source & "Renewable energy in general & $26 / 100$ \\
\hline \multirow[t]{5}{*}{ Priority } & Solar power & $16 / 100$ \\
\hline & Wind power & $16 / 100$ \\
\hline & Small-scale hydro power & $16 / 100$ \\
\hline & Geothermal power & $16 / 100$ \\
\hline & No specific target & $10 / 100$ \\
\hline \multirow[t]{4}{*}{ Source of Funding } & General tax revenues & $1 / 4$ \\
\hline & Added-value tax & $1 / 4$ \\
\hline & Tax on electricity (VAT) & 1/4, != Redistribution, exceptions* \\
\hline & Tax on electricity from non-renewable sources & $1 / 4, !=$ Redistribution, exceptions* \\
\hline \multirow[t]{4}{*}{ Policy Measure } & $\begin{array}{l}\text { Investment grants for the construction of a } \\
\text { new plant }\end{array}$ & $27 / 100$ \\
\hline & Feed-in tariff for renewable electricity & $27 / 100$ \\
\hline & $\begin{array}{l}\text { Tax reductions for firms that produce renewa- } \\
\text { ble electricity }\end{array}$ & $26 / 100$ \\
\hline & Redistribution to the population & 20/100, != General tax rev., VAT* \\
\hline \multirow[t]{5}{*}{ Costs } & No additional costs & $1 / 5$ \\
\hline & Around 8. - CHF additional monthly costs & $1 / 5$ \\
\hline & Around 15. - CHF additional monthly costs & $1 / 5$ \\
\hline & Around 23. - CHF additional monthly costs & $1 / 5$ \\
\hline & Around 30. - CHF additional monthly costs & $1 / 5$ \\
\hline \multirow[t]{2}{*}{ Exceptions } & No exceptions & $1 / 4$ \\
\hline & for energy intensive industries & 3/4, != General tax rev., VAT* \\
\hline \multirow[t]{3}{*}{ Nuclear Power Plants } & Close down within 5 years & $1 / 3$ \\
\hline & Maturity restriction of 60 years & $1 / 3$ \\
\hline & No maturity restriction & $1 / 3$ \\
\hline \multirow[t]{3}{*}{ Running Time } & for 10 years & $1 / 3$ \\
\hline & for 20 years & $1 / 3$ \\
\hline & for 35 years & $1 / 3$ \\
\hline
\end{tabular}

Notes: The attributes and levels were assigned to each task in a randomized way (see Hainmueller et al. 2014). *These combinations were excluded from the conjoint designs, since they do not represent reasonable variants of renewable electricity proposals. 
Table A.2. Data and descriptive statistics

\begin{tabular}{|c|c|}
\hline VARIABLE & VALUES \\
\hline Individuals & 4,146 for conjoint on policies \\
\hline Conjoint Ratings & $\begin{array}{l}7 \text { tasks } * 2 \text { concepts } * 4,146 \text { individuals }= \\
58,044\end{array}$ \\
\hline \multicolumn{2}{|l|}{ Support } \\
\hline from 1 (no support) to 11 (full support) & mean $=5.573$ \\
\hline \multicolumn{2}{|l|}{ Language } \\
\hline German & $66 \%$ \\
\hline French & $26 \%$ \\
\hline Italian & $9 \%$ \\
\hline \multicolumn{2}{|l|}{ Gender } \\
\hline male & $53 \%$ \\
\hline female & $47 \%$ \\
\hline \multicolumn{2}{|l|}{ Age } \\
\hline 18-35 years & $27 \%$ \\
\hline $36-50$ years & $29 \%$ \\
\hline 51-65 years & $28 \%$ \\
\hline $65+$ years & $16 \%$ \\
\hline \multicolumn{2}{|l|}{ Education } \\
\hline $\begin{array}{l}\text { low (no education, mandatory, pro- } \\
\text { fessional) }\end{array}$ & $47 \%$ \\
\hline middle (middle/higher professional) & $22 \%$ \\
\hline high (tertiary) & $31 \%$ \\
\hline \multicolumn{2}{|l|}{ Income } \\
\hline low (<4’999 CHF) & $26 \%$ \\
\hline middle (5’000-8’999 CHF) & $40 \%$ \\
\hline high (>=9’000 CHF) & $34 \%$ \\
\hline \multicolumn{2}{|l|}{ Left/Right } \\
\hline left & $23 \%$ \\
\hline middle & $52 \%$ \\
\hline right & $26 \%$ \\
\hline
\end{tabular}

Notes: Summary statistics refer to the subsample of individuals who answered the conjoint module. 
Table A.3. Citizens understanding of environmental taxes and modes of revenue recycling - the five items.

\begin{tabular}{|l|l|}
\hline 1 & An energy tax decreases energy consumption because it makes the consumption of energy more expensive. \\
\hline 2 & If revenues from an energy tax are redistributed to the population, energy consumption will not decrease. \\
\hline 3 & $\begin{array}{l}\text { An energy tax is a means to make those pay more who consume more energy. Saving energy means paying } \\
\text { less. }\end{array}$ \\
\hline 4 & $\begin{array}{l}\text { If revenues from an energy tax are redistributed to the population, this puts an additional strain on public } \\
\text { finances. }\end{array}$ \\
\hline 5 & $\begin{array}{l}\text { If revenues from an energy tax are used to reduce employers' contributions to a pension fund, the energy tax } \\
\text { has a double positive effect: reduction of energy consumption and an increase in employment. }\end{array}$ \\
\hline
\end{tabular}

Note: Response categories: Agree, rather agree, rather disagree, disagree, don’t know. Source: Own online survey in the context of the vote on the popular initiative "Green economy," September 2016. N = 1,020. 
Table A.4. Full results of model 1.

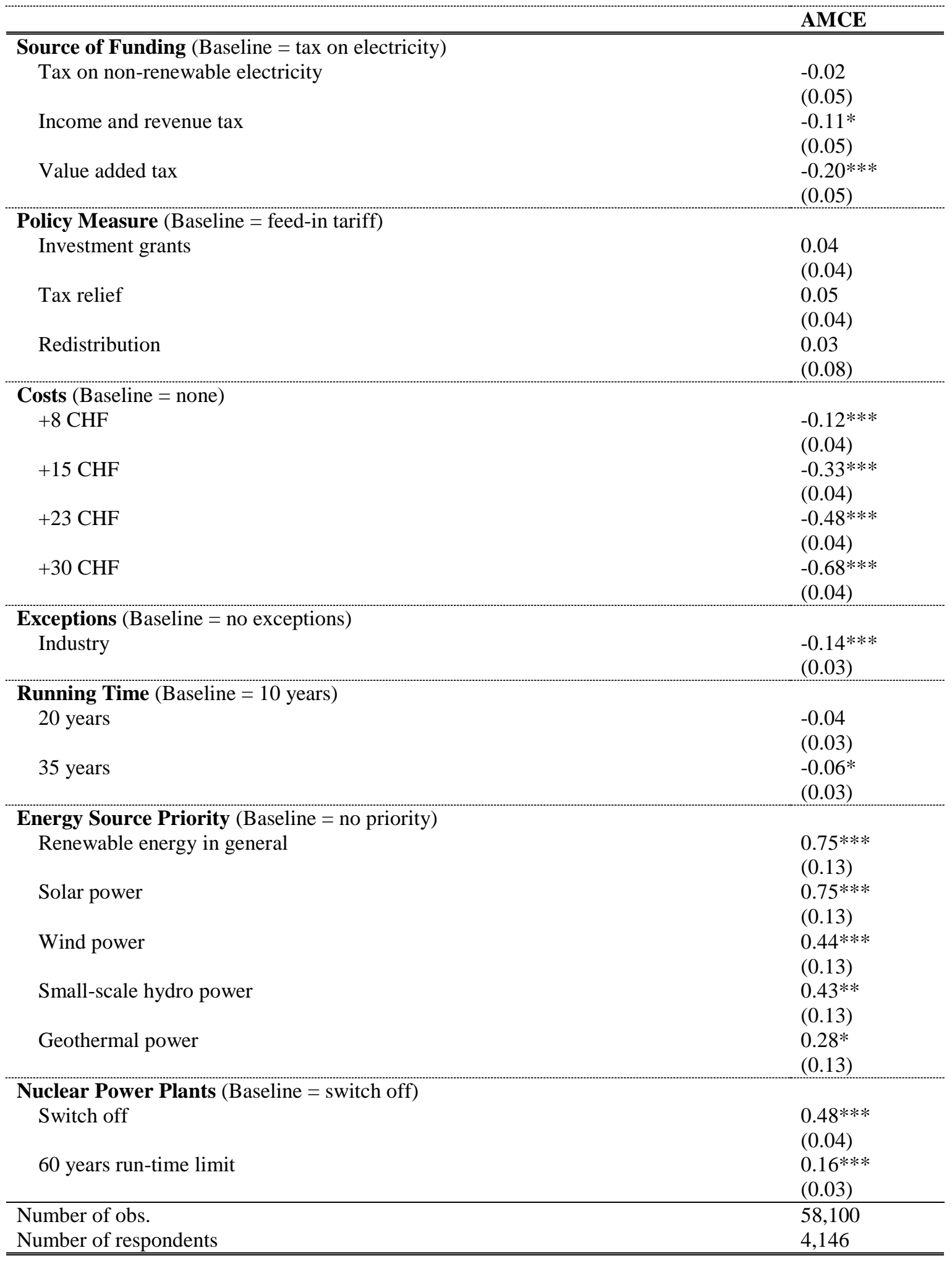

*** $p<0.001, * * p<0.01, * p<0.05$ 
Table A.5. Full results of model 1 - depending on ideological predispositions

\begin{tabular}{|c|c|c|c|c|}
\hline & AMCE & left & middle & right \\
\hline \multicolumn{5}{|c|}{ "Source of Funding (Baseline = tax on electricity) } \\
\hline Tax on non-renewable electricity & $\begin{array}{l}-0.05 \\
(0.05)\end{array}$ & $\begin{array}{l}-0.09 \\
(0.12)\end{array}$ & $\begin{array}{l}-0.01 \\
(0.07)\end{array}$ & $\begin{array}{l}-0.12 \\
(0.11)\end{array}$ \\
\hline Income and revenue tax & $\begin{array}{l}-0.11^{*} \\
(0.05)\end{array}$ & $\begin{array}{l}-0.17 \\
(0.11)\end{array}$ & $\begin{array}{l}-0.12 \\
(0.07)\end{array}$ & $\begin{array}{l}-0.06 \\
(0.10)\end{array}$ \\
\hline Value added tax & $\begin{array}{l}-0.21^{* * *} \\
(0.05)\end{array}$ & $\begin{array}{l}-0.13 \\
(0.11)\end{array}$ & $\begin{array}{l}-0.22 * * \\
(0.07)\end{array}$ & $\begin{array}{l}-0.25^{*} \\
(0.1)\end{array}$ \\
\hline \multicolumn{5}{|c|}{ Policy Measure (Baseline $=$ feed-in tariff) } \\
\hline Investment grants & $\begin{array}{l}0.06 \\
(0.05)\end{array}$ & $\begin{array}{l}0.10 \\
(0.10)\end{array}$ & $\begin{array}{l}0.01 \\
(0.06)\end{array}$ & $\begin{array}{l}0.13 \\
(0.1)\end{array}$ \\
\hline Tax relief & $\begin{array}{l}0.06 \\
(0.05)\end{array}$ & $\begin{array}{l}0.09 \\
(0.10)\end{array}$ & $\begin{array}{l}0.03 \\
(0.06)\end{array}$ & $\begin{array}{l}0.10 \\
(0.1)\end{array}$ \\
\hline Redistribution & $\begin{array}{l}0.02 \\
(0.09)\end{array}$ & $\begin{array}{l}0.24 \\
(0.19)\end{array}$ & $\begin{array}{l}-0.01 \\
(0.11)\end{array}$ & $\begin{array}{l}-0.06 \\
(0.18)\end{array}$ \\
\hline \multicolumn{5}{|l|}{ Costs (Baseline = none) } \\
\hline$+8 \mathrm{CHF}$ & $\begin{array}{l}-0.12^{* *} \\
(0.04)\end{array}$ & $\begin{array}{l}0.02 \\
(0.08)\end{array}$ & $\begin{array}{l}-0.15^{* *} \\
(0.05)\end{array}$ & $\begin{array}{l}-0.17^{*} \\
(0.08)\end{array}$ \\
\hline$+15 \mathrm{CHF}$ & $\begin{array}{l}-0.30 * * * \\
(0.04)\end{array}$ & $\begin{array}{l}-0.13 \\
(0.08)\end{array}$ & $\begin{array}{l}-0.32 * * * \\
(0.05)\end{array}$ & $\begin{array}{l}-0.4^{* * *} \\
(0.08)\end{array}$ \\
\hline$+23 \mathrm{CHF}$ & $\begin{array}{l}-0.47 * * * \\
(0.04)\end{array}$ & $\begin{array}{l}-0.28 * * * \\
(0.08)\end{array}$ & $\begin{array}{l}-0.52 * * * \\
(0.05)\end{array}$ & $\begin{array}{l}-0.53^{* * *} \\
(0.08)\end{array}$ \\
\hline$+30 \mathrm{CHF}$ & $\begin{array}{l}-0.66^{* * *} \\
(0.04)\end{array}$ & $\begin{array}{l}-0.44^{* * *} \\
(0.08)\end{array}$ & $\begin{array}{l}-0.68^{* * *} \\
(0.05)\end{array}$ & $\begin{array}{l}-0.81^{* * *} \\
(0.08)\end{array}$ \\
\hline \multicolumn{5}{|l|}{ Exceptions (Baseline = no exceptions) } \\
\hline Industry & $\begin{array}{l}-0.15^{* * *} \\
(0.04)\end{array}$ & $\begin{array}{l}-0.22 * * \\
(0.08)\end{array}$ & $\begin{array}{l}-0.16^{* * *} \\
(0.05)\end{array}$ & $\begin{array}{l}-0.05 \\
(0.07)\end{array}$ \\
\hline \multicolumn{5}{|l|}{ Running Time (Baseline $=10$ years) } \\
\hline 20 years & $\begin{array}{l}-0.04 \\
(0.03)\end{array}$ & $\begin{array}{l}-0.09 \\
(0.07)\end{array}$ & $\begin{array}{l}0.00 \\
(0.04)\end{array}$ & $\begin{array}{l}-0.04 \\
(0.06)\end{array}$ \\
\hline 35 years & $\begin{array}{l}-0.05 \\
(0.03)\end{array}$ & $\begin{array}{l}-0.05 \\
(0.06)\end{array}$ & $\begin{array}{l}-0.05 \\
(0.04) \\
\end{array}$ & $\begin{array}{l}-0.02 \\
(0.06)\end{array}$ \\
\hline \multicolumn{5}{|c|}{ Energy Source Priority (Baseline = no priority) } \\
\hline Renewable energy in general & $\begin{array}{l}0.79 * * * \\
(0.13)\end{array}$ & $\begin{array}{l}1.17 * * * \\
(0.30)\end{array}$ & $\begin{array}{l}0.79 * * * \\
(0.17)\end{array}$ & $\begin{array}{l}0.55^{*} \\
(0.28)\end{array}$ \\
\hline Solar power & $\begin{array}{l}0.78^{* * *} \\
(0.14)\end{array}$ & $\begin{array}{l}1.26 * * * \\
(0.32)\end{array}$ & $\begin{array}{l}0.75^{* * *} \\
(0.18)\end{array}$ & $\begin{array}{l}0.52 \\
(0.29)\end{array}$ \\
\hline Wind power & $\begin{array}{l}0.42 * * \\
(0.14)\end{array}$ & $\begin{array}{l}1.01 * * \\
(0.31)\end{array}$ & $\begin{array}{l}0.38 * \\
(0.18)\end{array}$ & $\begin{array}{l}0.06 \\
(0.29)\end{array}$ \\
\hline Small-scale hydro power & $\begin{array}{l}0.45^{* *} \\
(0.14)\end{array}$ & $\begin{array}{l}0.70 * \\
(0.31)\end{array}$ & $\begin{array}{l}0.45^{*} \\
(0.18)\end{array}$ & $\begin{array}{l}0.31 \\
(0.29)\end{array}$ \\
\hline Geothermal power & $\begin{array}{l}0.29 * \\
(0.14)\end{array}$ & $\begin{array}{l}0.71 * \\
(0.32)\end{array}$ & $\begin{array}{l}0.28 \\
(0.18) \\
\end{array}$ & $\begin{array}{l}0.07 \\
(0.29)\end{array}$ \\
\hline \multicolumn{5}{|c|}{ Nuclear Power Plants (Baseline $=$ switch off) } \\
\hline Switch off & $\begin{array}{l}0.48 * * * \\
(0.04)\end{array}$ & $\begin{array}{l}1.34^{* * * *} \\
(0.09)\end{array}$ & $\begin{array}{l}0.53^{* * *} \\
(0.05)\end{array}$ & $\begin{array}{l}-0.37 * * * \\
(0.08)\end{array}$ \\
\hline 60 years run-time limit & $\begin{array}{l}0.18 * * * \\
(0.03)\end{array}$ & $\begin{array}{l}0.37 * * * \\
(0.07)\end{array}$ & $\begin{array}{l}0.26 * * * \\
(0.04)\end{array}$ & $\begin{array}{l}-0.16^{* *} \\
(0.06)\end{array}$ \\
\hline $\begin{array}{l}\text { Number of obs. } \\
\text { Number of respondents }\end{array}$ & $\begin{array}{l}51,618 \\
3,683 \\
\end{array}$ & & & \\
\hline
\end{tabular}

*** $p<0.001, * * p<0.01, * p<0.05$ 


\section{Opinion on steering tax mechanism}

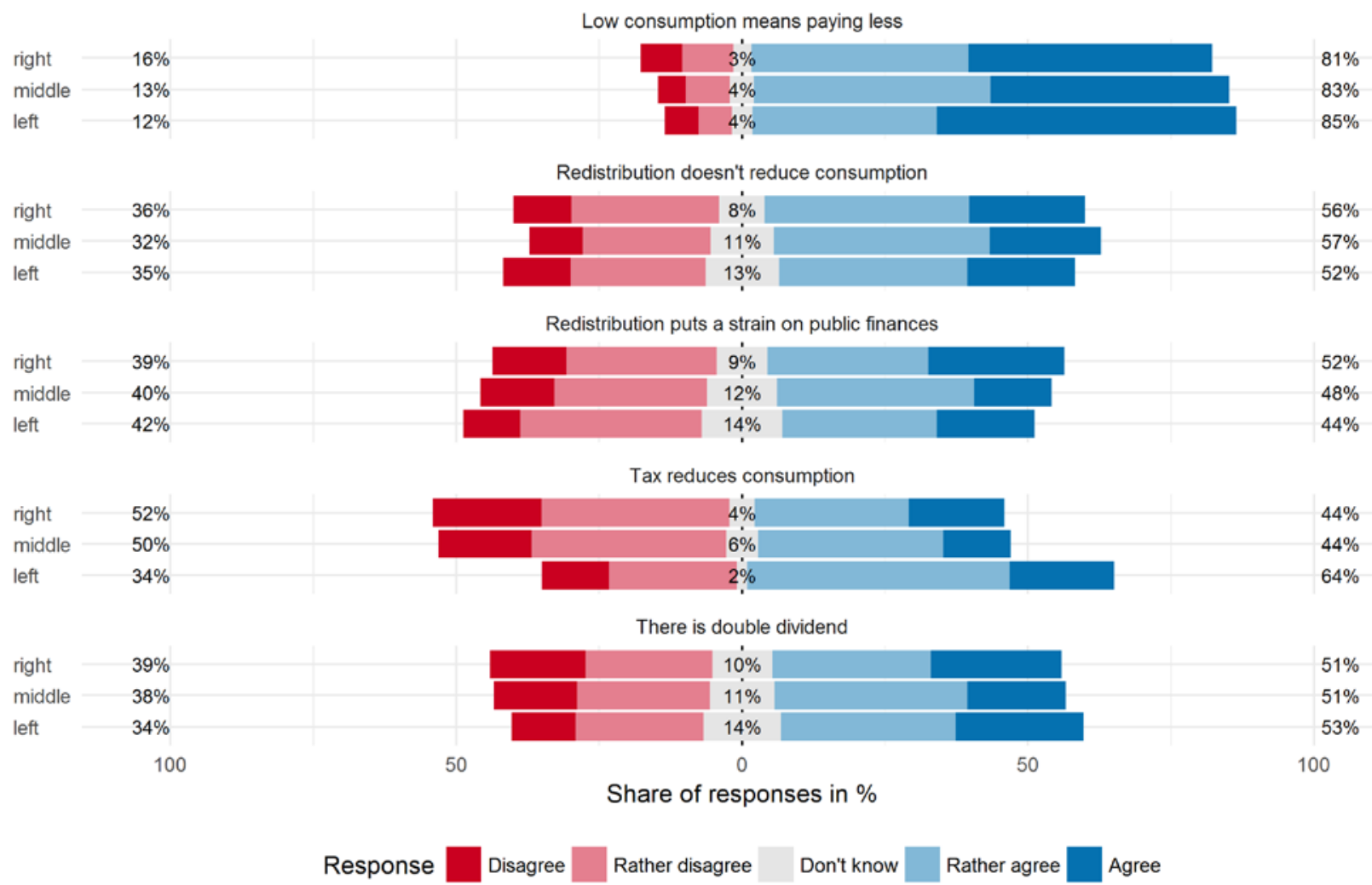

Fig. A1: What citizens of different political predispositions think about the elements of environmental taxes and modes of revenue recycling. Note: Share of respondents per category in \%. Source: Own data collected in the context of the vote on the popular initiative "Green economy," September 2016. Representative national sample, $\mathrm{N}=$ 912. The precise formulation of the items can be found in Table A.3 in the Appendix.

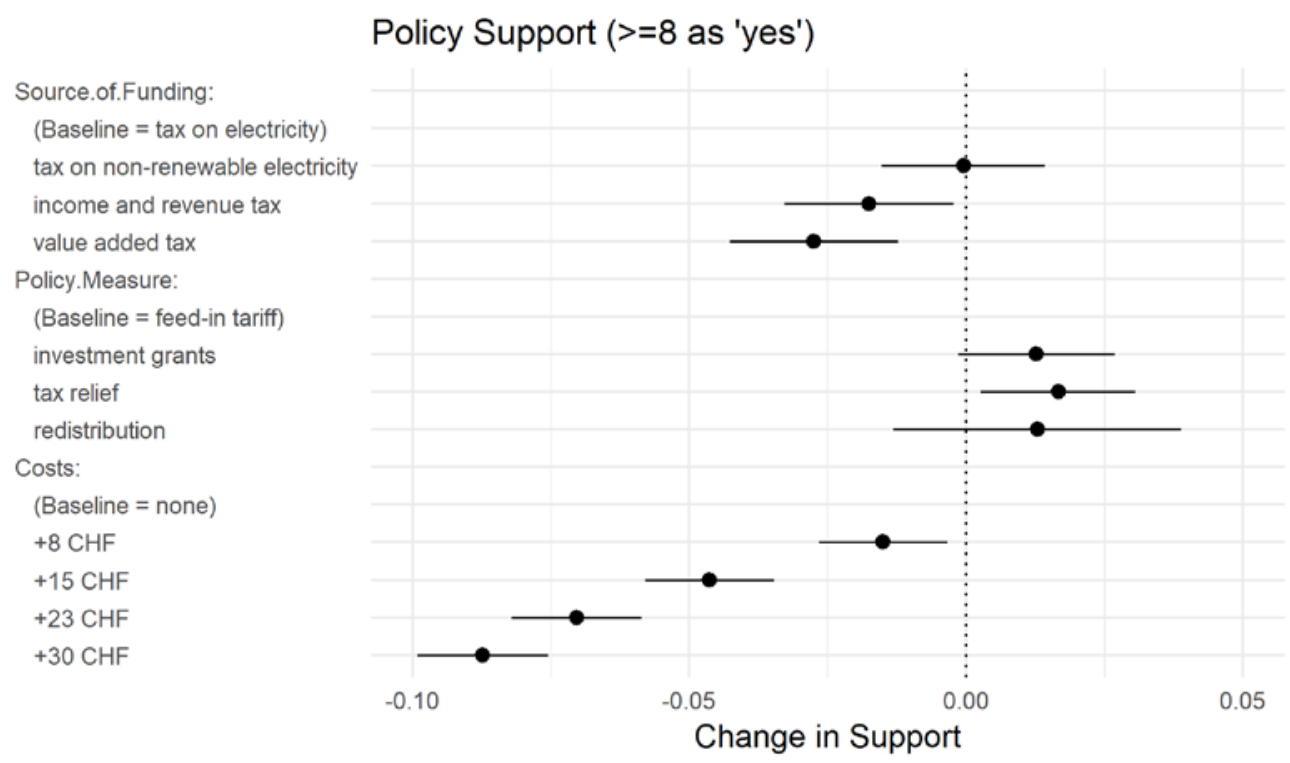

Fig. A2: Policy attributes and the probability that a proposal is chosen. Dependent variable: support as a dummy, coded ' 1 ' for values higher than or equal 8 , and ' 0 ' for lower values. Note: Average Marginal Component Effect (mean and 95\% confidence interval). Full results can be found in the supplemental material. 


\section{References}

Ajzen, I., Rosenthal, L. and Brown, T. (2000). Effects of perceived rairness on willingness to pay. Journal of Applied Social Psychology 30(12): 2439-2450.

Bechtel, M. M. \& Scheve, K. F. (2013). Mass support for global climate agreements depends on institutional design. Proceedings of the National Academy of Sciences of the United States of America 110(34): 13763-13768.

Bell, D., Gray, T., Haggett, C. \& Swaffield, J. (2013). Re-visiting the 'social gap': public opinion and relations of power in the local politics of wind energy. Environmental Politics 22(1): 115-135.

Bonoli, G. (2000). The politics of pension reform. Institutions and policy change in Western Europe. Cambridge: Cambridge University Press.

Borchers A.M., Duke J.M., \& Parsons, G.R. (2007). Does willingness to pay for green energy differ by source? Energy Policy 35(6): 3327-34.

Bornstein, N. \& Lanz, B. (2008). Voting on the environment: Price or ideology? Evidence from Swiss referendums. Ecological Economics 67(3): 430-440.

Bornstein, N. \& Thalmann, P. (2008). 'I Pay Enough Taxes Already!’ Applying Economic Voting Models to Environmental Referendums. Social Science Quarterly 89(5): 1336-1355.

Buchanan, J.M. and Tullock, G. (1975). Polluter's profits and political response: Direct control versus taxes. American Economic Review 65: 139-147.

Cairney, Paul. 2011. Understanding Public Policy. Chicago: Palgrave Macmillan.

Carattini, S.; Baranzini, A.; Thalmann Ph.; Varone F. \& F. Vöhringer (2016). Green taxes in a post-Paris world: are millions of nays inevitable? Centre for Climate Change Economics and Policy, Working Paper No. 273, Grantham Research Institute on Climate Change and the Environment Working Paper No. 243.

Chong, D., \& Druckman, J. N. (2007). A theory of framing and opinion formation in competitive elite environments. Journal of Communication 57(1): 99-118.

Clinch, P. J., \& L. Dunne (2006). Environmental tax reform: an assessment of social responses in Ireland. Energy Policy 34: 950-959. 
Deacon, R. \& Shapiro, P. (1975). Private Preference for Collective Goods Revealed Through Voting on Referenda. American Economic Review 65(5): 943--955.

Dermont, C.; Ingold, K.; Kammermann, L. \& Isabelle Stadelmann-Steffen (2017). Bringing the policy making perspective in: A political science approach to social acceptance. Energy Policy 108: 359-368.

Deroubaix, J.-F. \& Lévèque, F. (2006). The rise and fall of French Ecological Tax Reform: social acceptability versus political feasibility in the energy tax implementation process. Energy Policy 34(8): 940-949.

Dietz, T., Fitzgerald, A. \& Shwom, R. (2005). Environmental Values. Annu. Rev. Environ. Resourc 30(1): 335-372.

Dresner, S., Dunne, L., Clinch, P., Beuermann, Ch. (2006). Social and political responses to ecological tax reform in Europe: an introduction to the special issue. Energy Policy 34: 895904

Druckman, J. N. (2001). The implications of framing effects for citizen competence. Political behavior 23(3): 225-256.

Felder, S., \& R. Schleiniger (2002). Environmental tax reform: efficiency and political feasibility. Ecological Economics 42: 107-116.

Fransson, N. \& Gärlin, T. (1999). Environmental concern: Conceptual definitions, measurement methods, and research findings. Journal of Environmental Psychology 19: 369-382.

Grave K., et al. (2015). Electricity Costs of Energy Intensive Industries. An International Comparison. Fraunhöfer ISI \& Ecofys, http://www.isi.fraunhofer.de/isiwAssets/docs/x/de/projekte/Strompreiswirkung_330639/Industriestrompreise_englisch.pdf (retrieved August 4, 2016).

Gingrich, J. (2014). "Structuring the vote: welfare institutions and value-based vote choices", in: Kumlin, Staffan and Isabelle Stadelmann-Steffen (eds.), How Welfare States Shape the Democratic Public: Policy Feedback, Participation, Voting and Attitudes. Cheltenham, Edward Elgar Publishing Limited: 93-112.

Goulder, L. H. \& Parry I.W.H. (2008). Instrument Choice in Environmental Policy. Review of Environmental Economics and Policy 2(2): 152-174.

Hanley N, \& Nevin, C. (1999). Appraising renewable energy developments in remote commu- 
nities: the case of the North Assynt Estate Scotland. Energy Policy 27(9): 527-47.

Hainmueller, J., Hangartner, D. \& Yamamoto, T. (2015). Validating vignette and conjoint survey experiments against real-world behavior. Proc Natl Acad Sci USA 112(8): 2395-2400.

Hainmueller, J. \& Hopkins, D. J. (2014). The Hidden American Immigration Consensus: A Conjoint Analysis of Attitudes toward Immigrants. American Journal of Political Science 59(3): 529-548.

Hainmueller, J., Hopkins, D. J. \& Yamamoto, T. (2014). Causal Inference in Conjoint Analysis: Understanding Multidimensional Choices via Stated Preference Experiments. Political Analysis 22(1): 1-30.

Halbheer, D., Niggli, S. \& Schmutzler, A. (2006). What Does it Take to Sell Environmental Policy? An Empirical Analysis of Referendum Data. Environmental \& Resource Economics 33(4): 441-462.

Hartner, M., Rechberger, S.; Kirchler, E., and A. Schabmann, A. (2008). Procedural fairness and tax compliance. Economic analysis and policy 38(1): 137-152.

Häusermann, S. (2010). The politics of welfare state reform in continental Europe: Modernization in hard times. Cambridge: Cambridge University Press.

Häusermann, S., Kurer, Th. \& Traber, D. (2016). The Politics of Trade-offs: Studying the Dynamics of Welfare State Reform with Conjoint Experiments, Paper presented at the ECPR Joint Sessions, Pisa.

Häusermann, S., Traber, D. \& Kurer, T. (2015). Altersvorsorge 2020. Intakte Erfolgschancen trotz starkem Widerstand gegen Sparmassnahmen. Universität Zürich.

Howlett, M. (2005). What is a Policy Instrument? Tools, Mixes, and Implementation Styles. In Designing Government. From Instruments to Governance by Eliadis, P. et al. McGill Queen’s University Press, pp. 31-50.

Howlett, M. \& Ramesh, M. (1993). Patterns of Policy Instrument Choice: Policy Styles, Policy Learning and the Privatization Experience. Review of Policy Research 12(1): 3-24.

Howlett, M., Ramesh, M. \& Perl, A. (2009). Studying Public Policy: Policy Cycles and Policy Subsystems ( $3^{\text {rd }}$ edition). Oxford: Oxford University Press.

Ingold, K. (2008). Les mécanismes de décision: Le cas de la politique climatique Suisse. Politikanalysen. Zurich: Rüegger Verlag. 
Jaffe, A., Newell, R., Stavins, R. (2002a). A tale of two market failures: technology and environmental policy. Ecological Economics 54: 164-174.

Jaffe, A., Newell, R., Stavins, R. (2002b). Environmental policy and technological change. Environmental and Resource Economics 22: 41-69.

Kahn, M. E. \& Matsusaka, J. G. (1997). Demand for Environmental Goods: Evidence from Voting Patterns on California Initiatives. Journal of Law and Economics 40: 137-173.

Kahneman, D. and A. Tversky (1979). Prospect theory: an analysis of decision under risk. Econometrica 47: 263-291.

Kemp, R. and S. Pontoglio (2011). The innovation effects of environmental policy instruments - A typical case of the blind men and the elephant? Ecological Economics 72: 28-36.

Kirchgässner, G. (1997). Environmental policy in Switzerland: Methods, results, problems and challenges. In W. Wasserfallen (Ed.), Economic policy in Switzerland, Basingstoke, UK: Macmillan, 184-212.

Kirchgässner, G., \& F. Schneider (2003). On the political economy of environmental policy, Public Choice 115: 369-396.

Kollmuss, A. \& Agyeman, J. (2002). Mind the Gap: why do people act environmentally and what are the barriers to pro-environmental behavior? Environmental Education Research 8(3): 239-260.

Kriesi, H. (ed.) (2012). Political communication in direct-democratic campaigns. Enlightening or manipulating? Basingstoke: Palgrave.

Kriesi, H. (2005). Direct Democratic Choice. The Swiss Experience. Lanham: Lexington.

Lupia, A. (2015). Uninformed: Why people seem to know so little about politics and what we can do about it. Oxford University Press.

Lutz, Georg (2016). Eidgenössische Wahlen 2015. Wahlteilnahme und Wahlentscheid. Lausanne: Selects - FORS.

Marcantonini, C. \& A. D. Ellerman (2014). The implicit carbon price of renewable energy incentives in Germany. RSCAS Working Paper 2014/28, European University Institute.

Milfont, T. L. \& Duckitt, J. (2010). The environmental attitudes inventory: A valid and reliable measure to assess the structure of environmental attitudes. Journal of Environmental Psychology 30(1): 80-94. 
McDermott, R. (2004). Prospect Theory in Political Science: Gains and Losses from the First Decade. Political Psychology 25(2): 289-312.

Oberholzer-Gee, F., and H. Weck-Hannemann. (2002). Pricing road use: politico-economic and fairness considerations. Transportation Research Part D: Transport and Environment 7(5): 357-371.

OECD (2008). Promoting Sustainable Consumption. Good Practices in OECD Countries. Paris: OECD.

OECD (2006). The Political Economy of Environmentally Related Taxes. Paris: OECD.

Pasqualetti, M., Gipe P., \& Righter R. W. (2002). Wind Power in View. Energy Landscapes In A Crowded World. San Diego et al.: Academic Press.

Parry, I., and R. Williams (1999). A second-best evaluation of eight policy instruments to reduce carbon emissions. Resource and Energy Economics 21: 347-373.

Rausch, S., and V. J. Karplus (2014). Market vs. Regulation: The Efficiency and Distributional Impacts of U.S. Climate Policy Proposals. Energy Journal 35(1): 199-227.

Sciarini, P., Bornstein, N. \& Lanz, B. (2007). The Determinants of Voting Choices on Environmental Issues: A Two-Level Analysis. (This version: July 2007) Retrieved from bit.ly/1Ok61At.

Stadelmann-Steffen, I. (2011). Citizens as veto players: climate change policy and the constraints of direct democracy. Environmental Politics 20(4): 485-507.

Stigka, E.K., Paravantis, J.A. \& Mihalakakou G.K. (2014). Social acceptance of renewable energy sources: A review of contingent valuation applications. Renewable and Sustainable Energy Reviews 32: 100-106.

Swiss Confederation (2015). Botschaft zum Verfassungsartikel über ein Klima- und Energielenkungssystem. Bern.

Thalmann, P. (2004). The public acceptance of green taxes and million voters express and their opinion. Public Choice 119: 179-217.

van Rijnsoever, F.J., van Mossel, A., Broecks, K.P.F. (2015). Public acceptance of energy technologies: The effects of labeling, time, and heterogeneity in a discrete choice experiment. Renew Sust Energ Rew 45: 817-829. 
Vedung, E. (1998). Policy Instruments: Typologies and Theories. In Carrots, Sticks and Sermons: Policy Instruments and their Evaluation by Bemelmans-Videc, M.L., Rist, R.C. \& Vedung, E. (Eds.). New Brunswick and London: Transaction Publishers.

Volleberg, H., (2007). Impacts of Environmental Policy Instruments on Technological Change. OECD Report, 07-Feb-2007.

Windhoff-Héritier, A. (1987). Policy-Analyse. Eine Einführung. Frankfurt, New York: Campus.

Wolsink M. (2007). Wind power implementation: The nature of public attitudes: Equity and fairness instead of 'backyard motives'. Renewable and Sustainable Energy Reviews 11(6): 1188-1207. 


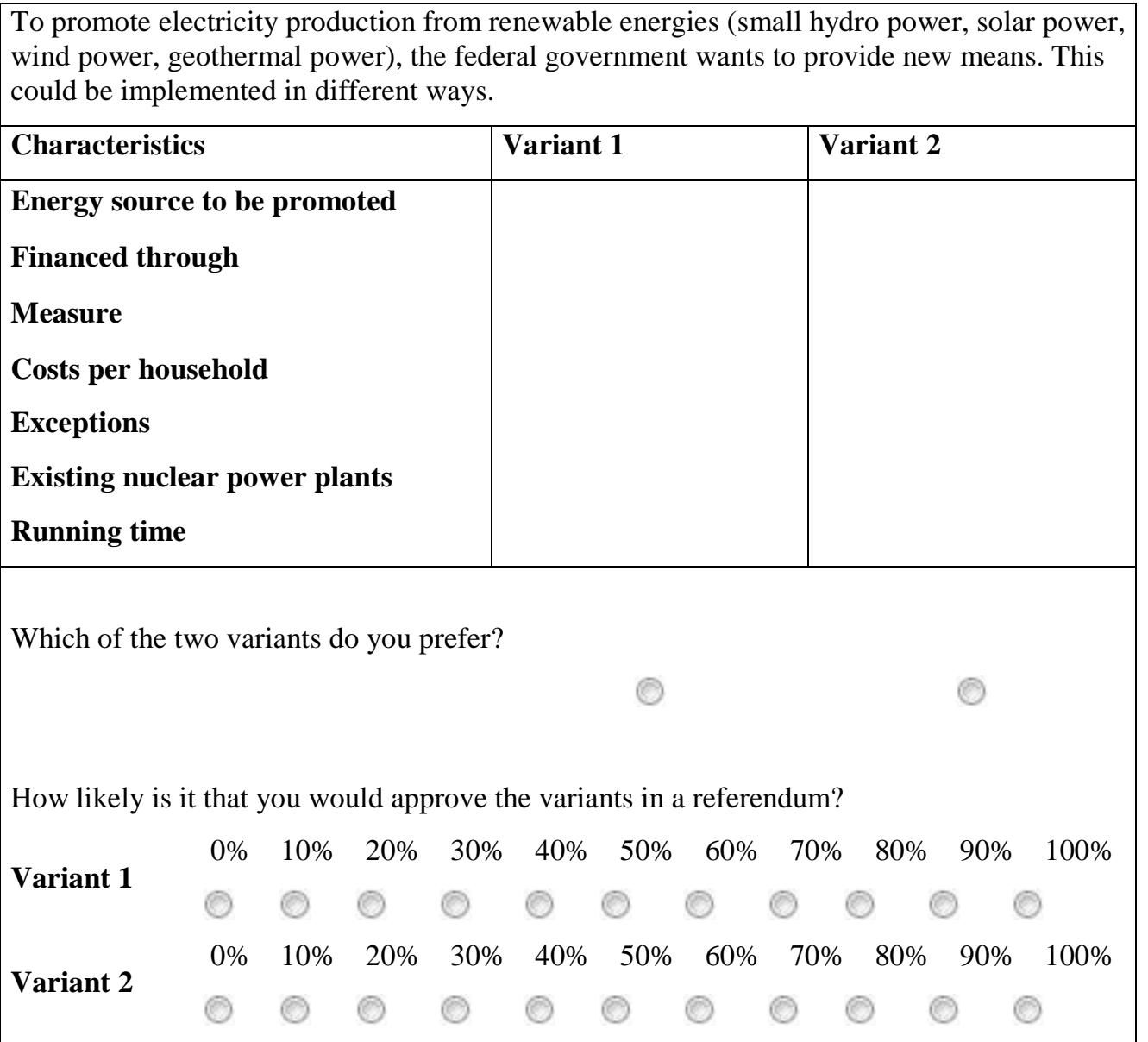

Fig. 1: Experimental Design: Setup of the question with the choice and support answers. The attribute order was randomized, whereby the two dimensions "Financed through" and "Measure" where kept together. 


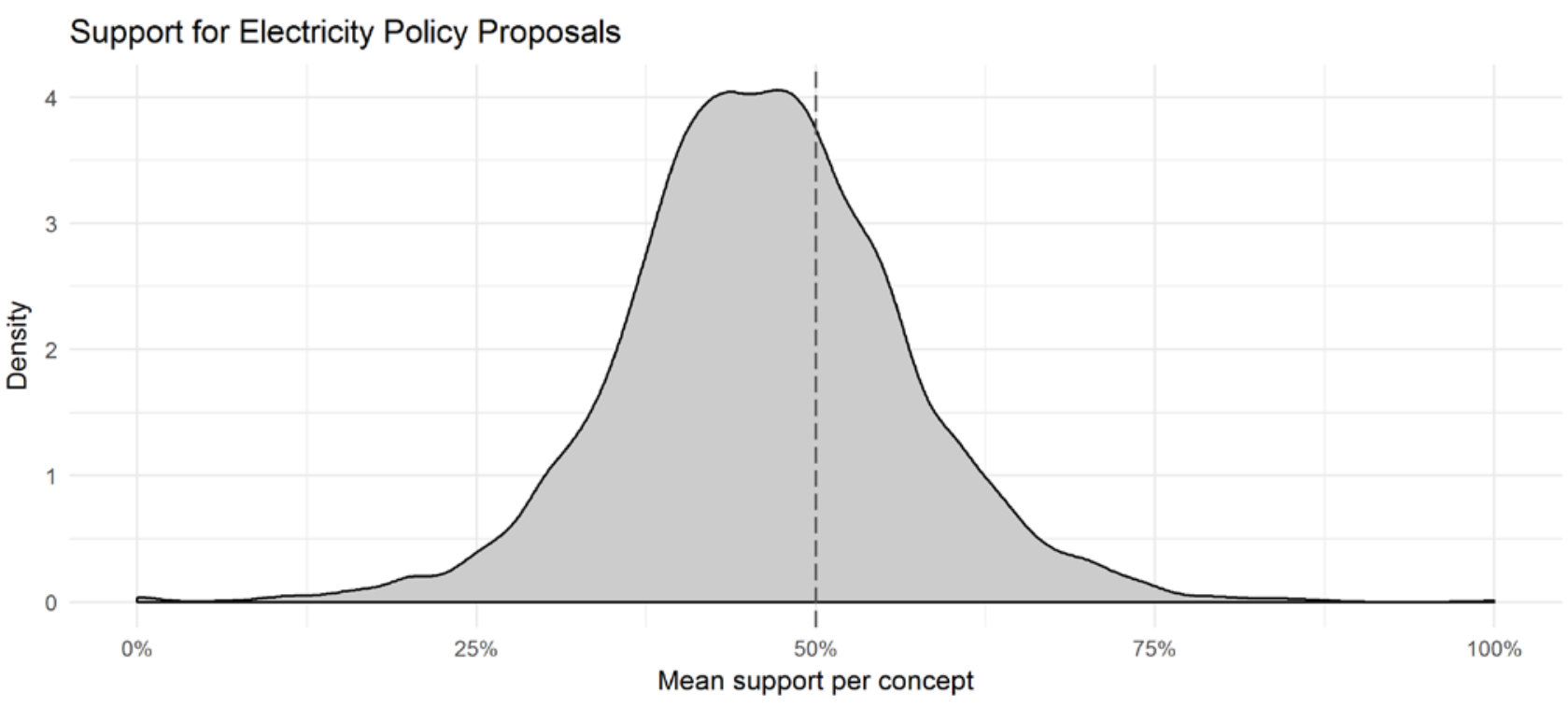

Fig. 2: Support of electricity policy proposals; mean reported support per proposal. 


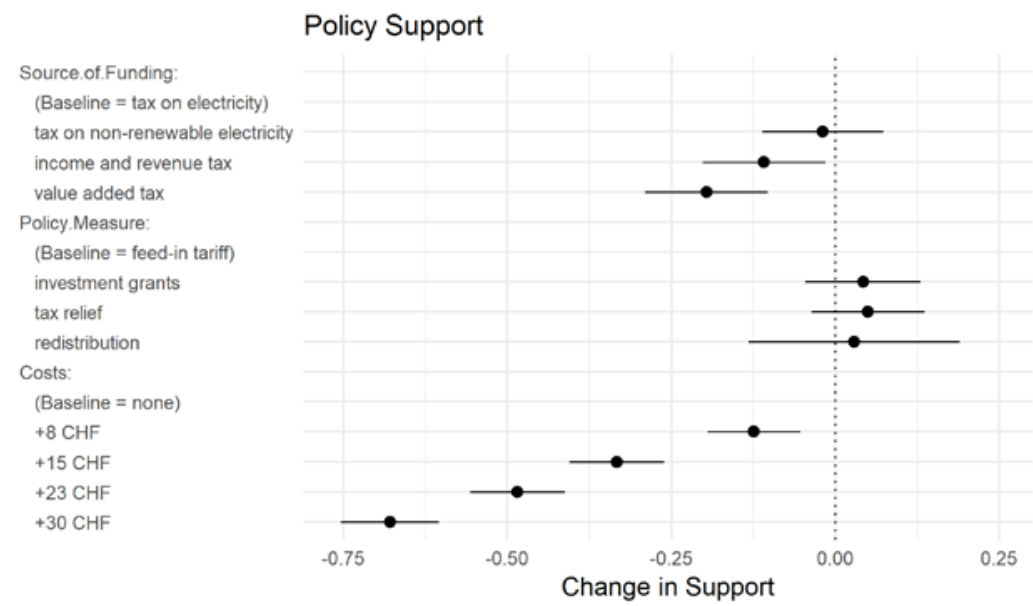

Fig. 3: Policy attributes and the probability that a proposal is chosen. Note: Average Marginal Component Effect (mean and 95\% confidence interval). Full results can be found in Table A.4. 


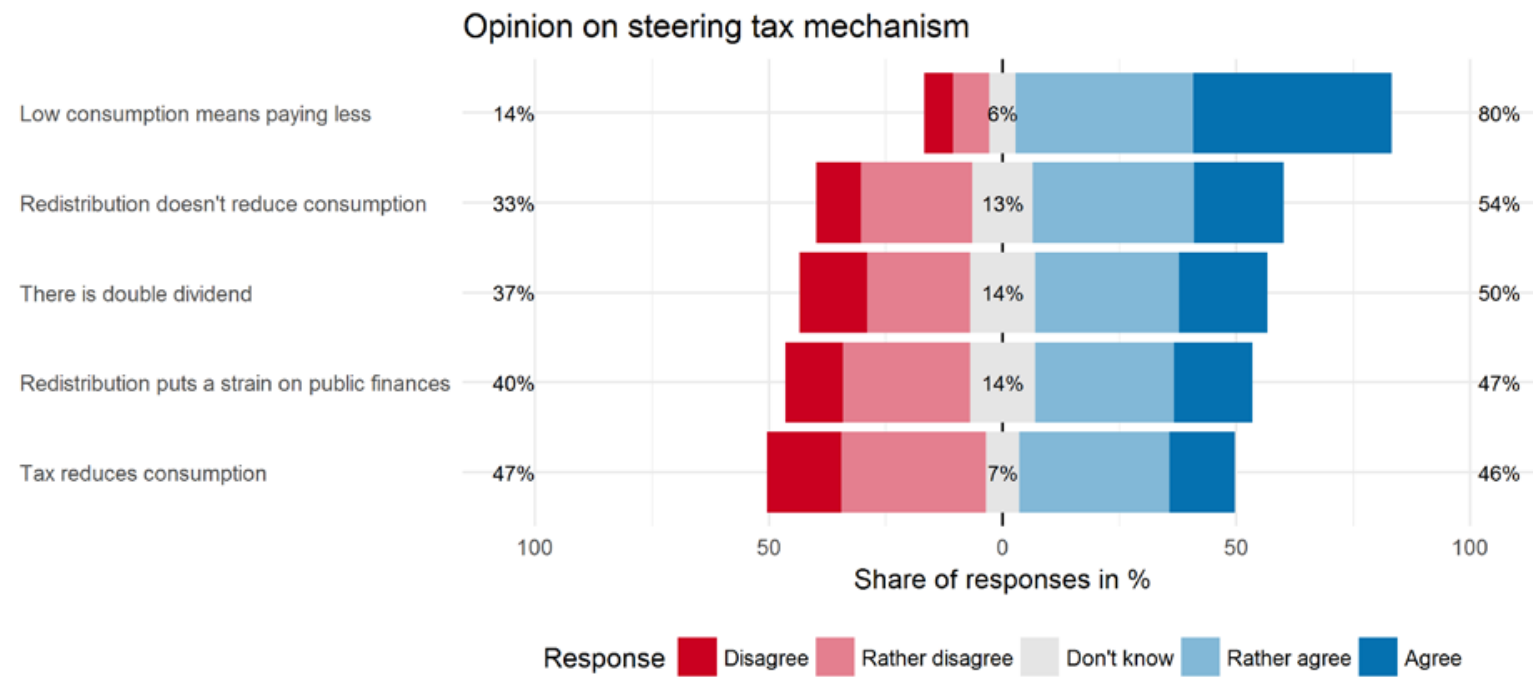

Fig. 4: What citizens think about elements of environmental taxes and modes of revenue recycling. Note: Share of respondents per category in percentages. Source: Our own data collected in the context of the vote on the popular initiative "Green economy," September 2016. Representative national sample $N=1,024$. The precise formulation of the items can be found in Table A.3 in the Appendix. 


\section{Policy Support by political ideology}

Source.of.Funding:
(Baseline $=$ tax on electricity)
tax on non-renewable electricity
income and revenue tax
value added tax
Policy. Measure:
(Baseline = feed-in tariff)
investment grants
tax relief
redistribution
Costs:
(Baseline = none)
$+8 \mathrm{CHF}$
$+15 \mathrm{CHF}$
$+23 \mathrm{CHF}$
$+30 \mathrm{CHF}$
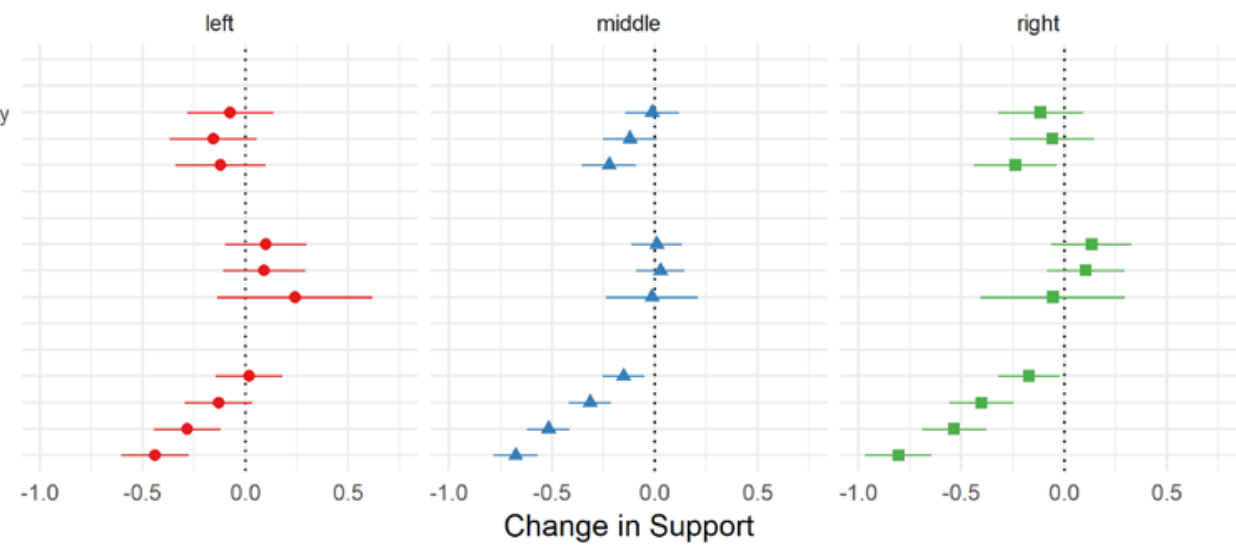

Political predisposition $\phi$ left $\uparrow$ middle $\phi$ right

Fig. 5: The effect of policy components by party-ideological voter groups. Note: Average Marginal Component Effect (mean and 95\% confidence interval). 


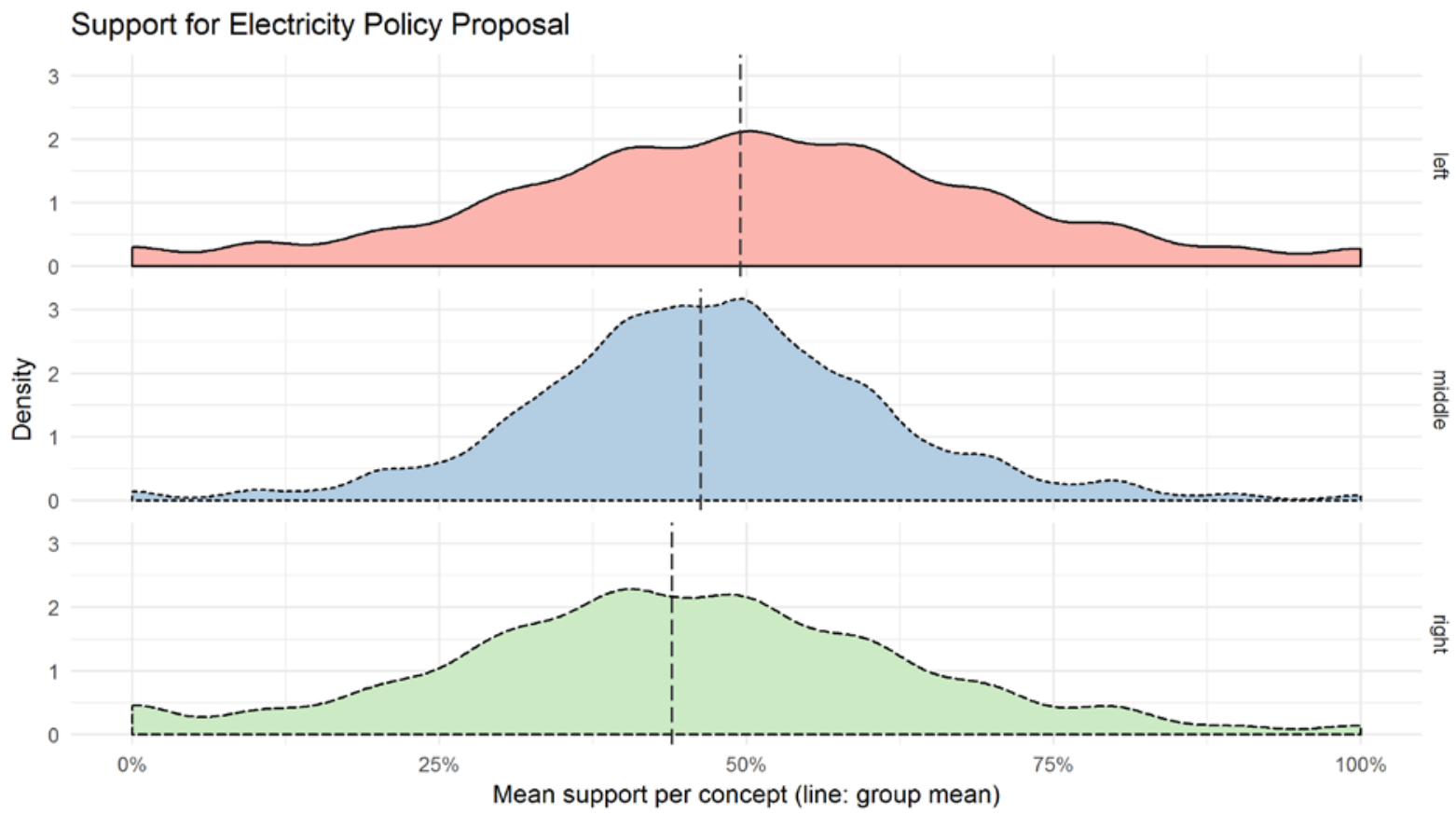

Fig. 6: Support of electricity policy proposals by political predisposition. Mean reported support per proposal. The dashed line represents the mean for each group, which is at $49.5 \%$ for left voters, $46.3 \%$ for the middle, and $43.9 \%$ for voters on the right. 